\title{
VÄITÖKSET
}

\section{Fyysisen ympäristön piirteet, kävelyvaikeudet ja fyysinen aktiivisuus iäkkäillä ihmisillä}

Useimmat meistä eivät ole voineet viimeisen vuoden aikana liikkua kuten olisimme halunneet. Covid-19-pandemian vuoksi asetetut kokoontumis- ja liikkumisrajoitukset ovat vaikuttaneet siihen, milloin, missä ja millä tavoin olemme voineet liikkua. Tämä on varmasti monestakin tuntunut ärsyttävältä, kenties myös vähentänyt päivittäisen liikkumisen määrää sekä muuttanut liikkumisen paikkoja ja tapoja. Jos liikkuminen on vähentynyt, fyysinen kunto on saattanut heiketä, ja kävellessämme lähistön mäet ovat voineet tuntua jopa aiempaa jyrkemmiltä.

Olemme olleet iästä riippumatta tilanteessa, joka on arkea monelle iäkkäälle ihmiselle.Tällä tarkoitan sitä, että erinäiset syyt asettavat rajoituksia fyysisesti aktiivisena olemiselle eikä liikkumista voi toteuttaa halutulla tavalla. On määritelty, että liikkuminen voi toteutua ideaalisti, kun yksilö voi turvallisesti ja luottavaisin mielin liikkua minne hän haluaa, milloin hän haluaa ja miten hän haluaa (Satariano ym. 2012). Rajoitukset paikan, ajan tai liikkumistavan suhteen ovat siis tekijöitä, jotka estävät liikkumisen toteuttamista. Määritelmä nostaa esille myös sen, että liikkumisen tulisi olla turvallista ja miellyttävää. Näihin asioihin voidaan vaikuttaa paitsi liikkeellä olevien kanssaihmisten toimin myös sillä, millaisiksi ympäristöt suunnitellaan.

Kodin lähiympäristö on iäkkäiden ihmisten tärkein liikkumisympäristö ja kävely yleisin vapaa-ajan fyysisen aktiivisuuden muoto (Chaudhury ym. 2016). Kävellen lähdetään paitsi ulkoilemaan ja lenkille myös toimittamaan arkiaskareita, kuten käymään kaupassa, harrastuksissa ja ystäviä tapaamassa. Vaikka paikka, johon suunnataan, sijaitsisikin kauempana kodista, kuljetaan sinne aina kodin lähiympäristön kautta. Ei siis ole yhdentekevää, kuinka houkuttava ja kävelyä mahdollistava lähiympäristö on, kun pitää päättää, lähteäkö liikkeelle jalkaisin vai moottoroidulla kulkupelillä. Tutkimuksissa onkin todettu, että iäkkäät ihmiset liikkuvat enemmän, jos asuinympäristössä on runsaasti houkuttavia määränpäitä ja kävelyä mahdollistavaa infrastruktuuria (Barnett ym.2017; Cerin ym.2017; Van Cauwenberg ym. 2018).

Monien iäkkäiden ihmisten, kuten nuorempienkin, kannattaisi joka tapauksessa lähteä liikkeelle jalkaisin vielä aiempaa useammin. Terveyden kannalta riittävän viikoittaisen liikkumisen määräksi suositellaan yli 65-vuotiaille vähintään 150 minuuttia reipasta tai $75 \mathrm{mi}^{-}$ nuuttia rasittavaa aerobista liikkumista, lihasvoimaa, notkeutta ja tasapainoa haastavaa liikuntaa kaksi kertaa viikossa sekä kevyttä liikuskelua ja taukoja paikallaanoloon mahdollisimman usein (UKK-instituutti 2019). Kuitenkin tuoreimman, vuoden 2017 FinHealth-tutkimuksen mukaan suomalaisista yli 65-74-vuotiaista vain 27 prosenttia ja yli 75-vuotiaista vain 12 prosenttia saavuttaa suositusten mukaisen aerobisen liikkumisen määrän (Bennie ym. 2017). Valtaosa ikääntyneistä henkilöistä siis liikkuu suosituksia vähemmän.

Lihasvoimin tapahtuva liikkuminen on terveyden ja toimintakyvyn kannalta tärkeää. Aiemmat tutkimukset ovat antaneet tästä runsaasti näyttöä. Lihasvoimin liikkuminen on fyysistä aktiivisuutta,joka voidaan määritellä li- 
hasten tahdonalaisena, energiankulutusta lisäävänä ja yleensä liikkeeseen johtavana toimintana. Suuremman fyysisen aktiivisuuden määrän on todettu pienentävän useiden sairauksien ja ennenaikaisen kuoleman riskiä (Bangsbo ym. 2019). Säännöllinen fyysinen aktiivisuus myös pienentää fyysisen toimintakyvyn rajoitteiden kehittymisen riskiä (Rantanen 2013). Fyysinen toimintakyky tarkoittaa ihmisellä olevia fyysisiä edellytyksiä selviytyä hänelle itselleen tärkeistä arjen tehtävistä.

Kävely on yksi tärkeä toiminto, johon fyysistä toimintakykyä tarvitaan. Kävely mahdollistaa myös muut liikkumistavat, kuten joukkoliikenteen käytön,ja kävelykyky auttaa elämään itsenäisesti vanhuudessa. Korkeaan ikään liittyy kuitenkin luonnollisia fysiologisia muutoksia, jotka näkyvät fyysisen toimintakyvyn heikkenemisenä. Liikkumiskykyä koskien ensimmäisiä tällaisia merkkejä on pidemmän matkan kävelyn vaikeutuminen (Rantanen 2013). Kun 500 metrin matkan kävely ei suju ilman vaikeuksia, voidaan liikkumiskyvyn todeta selkeästi alentuneen ja muodostavan riskin, että henkilö ei voi osallistua itsenäisesti kodin ulkopuolisiin aktiviteetteihin. Terveys 2011 -tutkimuksen mukaan yli 75-vuotiaista suomalaisista miehistä 35 prosenttia ja naisista 49 prosenttia koki ainakin jonkinasteisia vaikeuksia kävellä 500 metrin matka (Sainio ym. 2012). Kävelyvaikeuksien kokeminen on siis yleistä iäkkäässä väestössä.

Fyysinen toimintakyky on sidoksissa myös siihen ympäristöön, jossa arjen toiminnoista olisi tarkoitus suoriutua. On havaittu, että kävelyvaikeuksia kokevat iäkkäät ihmiset kertovat ympäristössään olevan enemmän liikkumista vaikeuttavia tekijöitä kuin ne, jotka eivät koe kävelyvaikeuksia (Skantz ym. 2020). Penkkien puuttuminen kävelyreittien varrelta ja kokemus siitä, että asiointi- tai muihin käyntikohteisiin on pitkä matka, lisäävät riskiä kävelyvaikeuksien kehittymiseen (Rantakokko ym. 2012). Toisaalta on havaittu, että vihreyden määrä iäkkäiden ihmisten lähiympäristössä samoin kuin vesi- ja luontoalueiden läheisyys liittyvät hitaampaan fyysisen toimintakyvyn heikkenemiseen (de Keijzer ym. 2019).

Asuinympäristöllä näyttää siis olevan yhteyttä niin kävelyvaikeuksien kehittymiseen kuin fyysisen aktiivisuuden määrään. Fyysisen ympäristön eli rakennetun ja luontoympäristön muokkaamisen onkin ajateltu olevan yksi keino vaikuttaa alueella asuvien ihmisten liikkumisen määrään ja fyysiseen toimintakykyyn. Siinä, miten asuinympäristöt tukevat fyysistä aktiivisuutta, on suuria eroja. Aikuisväestön fyysistä aktiivisuutta tarkastelleessa kansainvälissä tutkimuksessa todettiin, että fyysisen aktiivisuuden kannalta ympäristönpiirteiltään suotuisimmilla asuinalueilla voi viikkotasolla kertyä reipasta tai rasittavaa liikuntaa jopa 60 minuuttia enemmän kuin fyysistä aktiivisuutta vähiten tukevilla asuinalueilla (Sallis ym. 2016). Kysymys lihasvoimin liikkumista edistävästä ympäristöstä kytkeytyy siis myös yhtäläisten liikkumismahdollisuuksien tarjoamiseen ihmisille asuinpaikasta riippumatta. Kyse on lisäksi kestäviin liikkumistapavalintoihin kannustamisesta ja kaupunkirakenteen muutostarpeisiin vastaamisesta yhä suuremman osan väestöstä asuessa kaupunkiseuduilla. Käytännön toimia varten tarvittaisiin tietoa liikkumaan kannustavasta ympäristöstä muodossa, jota kaupunkisuunnittelussa käytettävät paikkatietojärjestelmät pystyvät hyödyntämään.

Millainen pitäisi siis asuinympäristön olla, jotta se edistäisi mahdollisimman monen ihmisen fyysistä aktiivisuutta? Samassa asuinympäristössähän asuu monenlaisia ihmisiä: iältään, toimintakyvyltään, tarpeiltaan ja toiveiltaan erilaisia. Asuinympäristöjä on myös hyvin monenlaisia. Kannustavatko samat toimet ihmisiä liikkumaan sekä maaseudulla että kaupunkien keskustoissa? Väitöskirjani pyrkii antamaan joitakin vastauksia näihin kysymyksiin. 


\section{Tutkimuskysymykset ja tutkimuksen toteutus}

Väitöstyöni tarkoituksena oli selvittää, ovatko asuinympäristön piirteiden yhteydet reippaan fyysisen aktiivisuuden määrään kontekstista riippumatta samanlaisia vai vaihtelevatko ne iäkkään henkilön kävelykyvyn, asuinalueen tyypin tai viikonpäivän mukaan. Lisäksi tutkin iäkkäiden ihmisten ulkona liikkumaan houkuttaviksi kokemien ympäristönpiirteiden yhteyksiä ympäristöä objektiivisesti kuvaaviin määreisiin - eli sitä, miltä houkuttavaksi koettu ympäristö voisi näyttää kartalla. Erityisesti pyrin löytämään houkuttavaksi koetulle lähiluonnolle objektiivisia vastinpareja. Houkuttavaksi koettujen ympäristönpiirteiden selville saaminen on tärkeää, sillä ne kertovat yksilön omakohtaisesta ympäristökokemuksesta ja juuri häntä ulkona liikkumaan motivoivista tekijöistä. Kun saadaan selville koettuja ympäristönpiirteitä vastaavia ympäristöä objektiivisesti kuvaavia tekijöitä, voidaan iäkkäiden ihmisten liikkumista koskevia tarpeita ja mieltymyksiä huomioida ympäristönsuunnittelussa. Lisäksi ympäristönpiirteiden kokemisessa heijastuu fyysinen toimintakyky. Väitöstutkimuksessa halusinkin myös selvittää, miten suuri merkitys lähiympäristön piirteillä on iäkkäiden ihmisten fyysiselle aktiivisuudelle verrattuna muihin fyysistä aktiivisuutta muokkaaviin tekijöihin. Tätä varten vertasin toisiinsa kodin lähistöllä olevien tiettyjen ympäristönpiirteiden määrän ja kävelyvaikeuksien kokemisen yhteyksiä päivittäisen fyysisen aktiivisuuden määrään.

Tein väitöstutkimuksen osana GEOagetutkimushanketta (Portegijs ym. 2017), jossa yhdistin iäkkäiltä ihmisiltä kerättyä tietoa ympäristöä objektiivisesti kuvaavaan paikkatietoon. Tutkimuksessa käytin Iäkkäiden ihmisten liikkumiskyky ja elinpiiri -tutkimushankkeen eli LISPE-tutkimuksen (Rantanen ym. 2012) aineistoa, johon oli kerätty tietoja strukturoidulla haastattelulla, toimintakykymittauksilla ja kiihtyvyysmittarilla kotona asuvilta 75-90-vuotiailta jyväskyläläisiltä ja muuramelaisilta henkilöiltä. Tutkimuksessa oli mukana sen alkaessa vuonna 2012 yhteensä 848 henkilöä, joista 167:1tä rekisteröitiin kiihtyvyysmittarilla fyysistä aktiivisuutta seitsemän päivän ajan. Kaksi vuotta myöhemmin tehtyyn seurantahaastatteluun osallistui 761 henkilöä. Osallistuminen oli kaikille vapaaehtoista, ja tutkimushankkeelle oli saatu myöntävä lausunto Jyväskylän yliopiston eettiseltä toimikunnalta. Keräsin ympäristönpiirteiden tiedot avoimista paikkatietoaineistoista, joita olivat tuottaneet lähinnä suomalaiset virastot ja tutkimuslaitokset. Paikkatietoaineistot antoivat siis objektiivista tietoa tiettyyn sijaintiin liittyvistä ympäristönpiirteistä. Erityisesti tarkastelin maankäyttöä, vesialueita, tieverkoston tiheyttä ja jyrkkyyttä, yhdyskuntarakennetta ja väestöntiheyttä.

\section{Fyysisen aktiivisuuden ja ympäristön- piirteiden yhteydet osoittautuivat kontekstista riippuvaisiksi}

Väitöstyössä tuli esille ulkona liikkumista tukevan infrastruktuurin ensisijainen tärkeys reippaan fyysisen aktiivisuuden karttumiselle. Tällaista infrastruktuuria ovat esimerkiksi katuvalaistus sekä rauhalliset ja hyväpintaiset kävelytiet. Tulos ei ollut yllätys, sillä asiasta oli jo aiempaa vahvaa näyttöä (Barnett ym. 2017; Cerin ym. 2017; Van Cauwenberg ym. 2018). Lisäksi väitöstutkimus paljasti, että liikkumista tukevan infrastruktuurin määrä heijastuu siihen, millaiset ulkona liikkumaan houkuttavaksi koetut tekijät lopulta yhdistyivät iäkkäiden ihmisten reippaaseen liikkumiseen. Erityyppisiä asuinalueita tarkasteltaessa nimittäin havaittiin, että vaikka tutkittavat kokivat luontopohjaiset kohteet, kuten järvenrannat ja pururadat, asuinalueesta riippumatta yhdeksi heitä eniten ulkona liikkumaan houkuttavista ympäristötekijöistä, tällaisia houkuttavia kohteita kokevat iäkkäät ihmiset saavuttivat suuremman liikkumisen määrän vain asuessaan alueilla, joilla oli enemmän liikkumista tukevaa infrastruktuuria. Käytännössä näitä alueita olivat keskusta- 
alueet sekä tiheän asutuksen alueet keskustojen lähistöillä. Sen sijaan harvan asutuksen alueilla, joilla ulkona liikkumista tukevaa infrastruktuuria oli yleisesti ottaen vähemmän, kodin lähistön kävelymahdollisuuksia parantavat tekijät yhdistyivät siihen, että iäkkäille ihmisille kertyi reipasta liikkumista enemmän. Vaikuttaa siis siltä, että reippaan liikkumisen karttumiseksi runsaammassa määrin liikkumisen pitäisi olla mahdollista turvallisesti ja mukavasti laajemmalla alueella - ideaalimmat liikkumisen mahdollisuudet näkyvät myös suurempana toteutuneena liikkumisen määränä.

Fyysiseen aktiivisuuteen vaikuttaa myös se, että asuinalueella on kohteita, joihin on luontevaa suunnata kävellen. Tiheästi asutut alueet tarjoavat enemmän mahdollisuuksia osallistua järjestettyihin aktiviteetteihin ja hoitaa asioita kävellen kuin haja-asutusalueet, ja tämä näkyy iäkkäiden ihmisten runsaampana fyysisenä aktiivisuutena suuremman asukastiheyden alueilla. Asiointikohteiden läheisyydellä näyttäisi olevan merkitystä fyysisen aktiivisuuden kartuttajana juuri arkisin, sillä asukastiheys ja tieverkoston risteystiheys, joiden voi ajatella heijastavan myös asiointikohteiden runsautta, yhdistyivät liikkumisen määrään vain arkipäivisin, eivät viikonloppuisin. Sen sijaan asuinympäristössä olevien luonnonpiireiden yhteys fyysisen aktiivisuuden karttumiseen oli samankaltaista arkipäivisin ja viikonloppuisin. Iäkkäät ihmiset, joilla oli monentyyppisiä elinympäristöjä sisältävä laaja luonto- tai viheralue kodin lähellä, liikkuivat sekä arkisin että viikonloppuisin runsaammin kuin ne, joiden lähistöllä ei ollut yhtä monimuotoista viheraluetta. Kodin lähistön teiden ollessa mäkisiä fyysisen aktiivisuuden määrä jäi keskimäärin vähäisemmäksi ja iäkkäät ihmiset liikkuivat harvemmin yli 10 minuutin yhtäjaksoisia rupeamia kuin tasamaalla asuvat viikonpäivästä riippumatta. Luontoalueet ovat auki ja mäet paikallaan viikon jokaisena päivänä. Ympäristönpiirteet voivat vaikuttaa siihen, millaisia fyysistä aktiivisuutta kartuttavia rutiineja eri viikonpäiville muodostuu.
Monimuotoinen iso luonto- tai viheralue näyttäisi siis houkuttavan liikkumaan ulkona, ja sellaisen lähistöllä asuville iäkkäille ihmisille kertyy enemmän fyysistä aktiivisuutta. Näin oli erityisesti niillä iäkkäillä ihmisillä,joilla ei ollut kävelyvaikeuksia. Kun kodin lähistöllä oli jokin vesialue, iäkkäille ihmisille kertyi enemmän reipasta liikkumista riippumatta siitä, kokivatko he kävelyvaikeuksia vai eivät. Tutkimuksessa esille tullut suuremman mäkisyyden yhteys vähäisempään fyysiseen aktiivisuuteen ei riippunut kävelyvaikeuksien kokemisesta. Liikkuminen harvemmin kodin ulkopuolella ja kodin läheisten teiden suurempi mäkisyys kasvattivat kävelyvaikeuksien kehittymisen riskiä. Tulos vähäisen fyysisen aktiivisuuden yhteydestä kävelyvaikeuksien kehittymiseen on aiempien tutkimustulosten mukainen ja korostaa fyysisen aktiivisuuden merkitystä fyysisen toimintakyvyn ylläpitäjänä. Tulos tieverkoston objektiivisesti määritetyn jyrkkyyden ja kävelyvaikeuksien kehittymisen yhteydestä oli uusi havainto. Tutkimuksen perusteella voidaan siis ehdottaa, että kodin läheisen tieverkoston suuri mäkisyys tulisi huomioida kävelyvaikeuksien kehittymiselle altistavana riskitekijänä.

Verratessa tutkimukseen osallistuneiden henkilöiden kodin lähiympäristöjä toisiinsa todettiin niiden välillä suuria eroja liikkumista tukevien ympäristönpiirteiden määrissä. Kuinka suuri ero reippaan fyysisen aktiivisuuden kertymiselle voisi olla sillä, asuuko henkilö ympäristönpiirteiltään liikkumista eniten vai vähiten tukevassa asuinympäristössä? Kun arvioin tätä, totesin, että kertyvän fyysisen aktiivisuuden määrä voisi erota tällaisissa ympäristöissä asuvien välillä yhtä paljon kuin keskimäärin eroavat toisistaan kävelyvaikeuksia kokemattomien ja niitä kokevien iäkkäiden ihmisten fyysisen aktiivisuuden määrät. Ulkona liikkumista tukevien ympäristönpiirteiden määrä näyttää siis todella vaikuttavan iäkkäiden ihmisten reippaaseen fyysiseen aktiivisuuteen. 


\section{Ympäristönpiirteet ovat resurssi fyysiselle aktiivisuudelle}

Yhteenvetona väitöstyön tuloksista voidaan todeta, että se, millaisessa ympäristössä asuville kertyy suurempi määrä reipasta liikkumista, on yhteydessä resursseihin: sekä yksilön, erityisesti fyysistä toimintakykyä mahdollistaviin, resursseihin että ympäristön liikkumista haastaviin tai mahdollistaviin piirteisiin ja liikkumaan houkuttaviin kohteisiin (ks. myös Lawton \& Nahemow 1973). Ympäristön ja fyysisen aktiivisuuden välisissä yhteyksissä on kyse myös yksilön mahdollisuuksista aktiiviseen toimijuuteen eli mahdollisuuksiin tehdä valintoja ja toimia näiden valintojen mukaisesti oman toimintakyvyn ja ympäristön olosuhteiden asettamissa rajoissa (ks. myös Baltes \& Baltes 1990). Asuinympäristöjen kehittäminen iäkkäiden ihmisten fyysistä aktiivisuutta edistäväksi vaatii siis kontekstin huomiointia: esimerkiksi paikallisten olosuhteiden tunnistamista sekä ymmärrystä fyysisen toimintakyvyn heijastumisesta siihen, millaiset ympäristönpiirteet edesauttavat runsaampaa liikkumista. Ylipäätään ympäristönpiirteet tulisi nähdä varteenotettavina resursseina, jotka tukevat iäkkäiden ihmisten fyysistä aktiivisuutta ja toimintakyvyn ylläpitoa.

Kirsi Keskinen, FT

kirsi.e.keskinen@jyu.fi

Gerontologian ja kansanterveyden alaan kuuluva väitöskirja "Features of the physical environment, walking difficulty, and physical activity in old age" tarkastettiin Jyväskylän yliopistossa 11.6.2021.

\section{Kirjallisuutta}

Baltes PB, Baltes MM. Psychological perspectives on successful aging: the model of selective optimization with compensation. In: Baltes $\mathrm{PB}$, Baltes $M M$, ed. Successful aging: perspectives from the behavioral sciences. New York: Cambridge University Press, 1990:1-34.
Bangsbo J, Blackwell J, Boraxbekk CJ, Caserotti P, Dela F, Evans AB, et al. Copenhagen Consensus statement 2019: physical activity and ageing. Brit J Sport Med 2019;53(14):856-8.

http://dx.doi.org/10.1136/

bjsports-2018-100451

Barnett DW, Barnett A, Nathan A, Van Cauwenberg J, Cerin E (the Council on Environment and Physical Activity (CEPA) - Older Adults working group). Built environmental correlates of older adults' total physical activity and walking: a systematic review and meta-analysis. Int J Behav Nutr Phy 2017;14:e103. https://doi.org/10.1186/s12966-017-0558-z

Bennie JA, Pedisic Z, Suni JH, Tokola K, Husu P, Biddle SJH, et al. Self-reported health-enhancing physical activity recommendation adherence among 64,380 Finnish adults. Scand J Med Sci Spor 2017;27(12):1842-53. https://doi.org/10.1111/sms.12863

Cerin E, Nathan A, Van Cauwenberg J, Barnett DW, Barnett A. The neighbourhood physical environment and active travel in older adults: a systematic review and meta-analysis. Int J Behav Nutr Phy 2017;14:e15. https://doi.org/10.1186/ s12966-017-0471-5

Chaudhury H, Campo M, Michael Y, Mahmood A. Neighbourhood environment and physical activity in older adults. Soc Sci Med 2016;149:104-13. https://doi.org/10.1016/j.socscimed.2015.12.011 de Keijzer C, Tonne C, Sabia S, Basagaña X, Valentín A, Singh-Manoux A, et al. Green and blue spaces and physical functioning in older adults: longitudinal analyses of the Whitehall II study. Environ Int 2019;122:346-56. https://doi.org/10.1016/j.envint.2018.11.046

Keskinen KE. Features of the physical environment, walking difficulty, and physical activity in old age. JYU dissertations 391. 2021.

http://urn.fi/URN:ISBN:978-951-39-8682-7

Lawton MP, Nahemow L. Ecology and the aging process. In: Eisdorfer C, Lawton MP, ed. The psychology of adult development and aging. Washington, DC: American Psychological Association, 1973:619-74.

Portegijs E, Keskinen KE, Tsai LT, Rantanen T, Rantakokko M. Physical limitations, walkability, perceived environmental facilitators and physical activity of older adults in Finland. Int J Environ Res Public Health 2017;14:e333. https://doi.org/10.3390/ijerph14030333 
Rantakokko M, Iwarsson S, Mänty M, Leinonen R, Rantanen T. 2012. Perceived barriers in the outdoor environment and development of walking difficulties in older people. Age Ageing 2012;41(1):118-21. https://doi.org/10.1093/ageing/afr136

Rantanen T. Promoting mobility in older people. J Prev Med Public Health 2013;46:S50-4. http:// dx.doi.org/10.3961/jpmph.2013.46.S.S50

Rantanen T, Portegijs E, Viljanen A, Eronen J, Saajanaho M, Tsai LT, et al. Individual and environmental factors underlying life space of older people - study protocol and design of a cohort study on life-space mobility in old age (LISPE). BMC Public Health 2012;12:e1018. https://doi.org/10.1186/1471-2458-12-1018

Sainio P, Stenholm S, Vaara M, Rask S, Valkeinen H, Rantanen T. Fyysinen toimintakyky. Teoksessa: Koskinen S, Lundqvist A, Ristiluoma N, toim. Terveys, toimintakyky ja hyvinvointi Suomessa 2011. Raportti 68/2012. Helsinki: Terveyden ja hyvinvoinnin laitos (THL), 2012:120-4. http://urn.fi/URN:ISBN:978-952-245-769-1

SallisJF, Cerin E, Conway TL, Adams MA, Frank LD, Pratt $\mathrm{M}$, et al. Physical activity in relation to urban environments in 14 cities worldwide: a cross-sectional study. Lancet 2016;387(10034):2207-17. https://doi.org/10.1016/S0140-6736(15)012842 Erratum in: Lancet 387(10034):2198.
Satariano WA, Guralnik JM, Jackson RJ, Marottoli RA, Phelan EA, Prohaska TR. Mobility and aging: new directions for public health action. Am J Public Health 2012;102(8):1508-15. https://doi.org/10.2105/AJPH.2011.300631

Skantz H, Rantanen T, Rantalainen T, Keskinen KE, Palmberg L, Portegijs E, et al. Associations between perceived outdoor environment and walking modifications in community-dwelling older people: a two-year follow-up study. J Aging Health 2020;32(10):1538-51. https://doi.org/10.1177/0898264320944289

UKK-Instituutti. Vireyttä liikkumalla. Viikoittainen liikkumisen suositus yli 65-vuotiaille. 2019. Internet: https://ukkinstituutti.fi/liikkuminen/ liikkumisen-suositukset/liikkumisen-suositus-yli-65-vuotiaille/ (viitattu 26.3.2021).

Van Cauwenberg J, Nathan A, Barnett A, Barnett DW, Cerin E (the Council on Environment and Physical Activity (CEPA) - Older Adults, Working Group). Relationships between neighbourhood physical environmental attributes and older adults' leisure-time physical activity: a systematic review and meta-analysis. Sports Med 2018;48(7):1635-60. https://doi.org/10.1007/s40279-018-0917-1 